\title{
Aleppo pine regeneration after fire along an aridity gradient
}

\author{
J. De las Heras ${ }^{1}$, D. Moya ${ }^{1}$, F. R. López-Serrano ${ }^{1}$, M. Eugenio ${ }^{2}$ \\ \& J. M. Espelta ${ }^{2}$ \\ ${ }^{1}$ Escuela Técnica Superior de Ingenieros Agrónomos de Albacete, \\ Universidad de Castilla-La Mancha, Spain \\ ${ }^{2}$ CREAF, Universidad Autonóma de Barcelona, Bellaterra, Spain
}

\begin{abstract}
In the Mediterranean Basin, the number of large-scale fires and, consequently, the area of regenerated forests after a fire have been increasing over the last few decades. Mediterranean pine tree stand regeneration shows differences in growth and reproductive characteristics depending on site quality. Aleppo pine (Pinus halepensis Mill.) is an important obligate seeder species occupying a large surface in this area. In order to study growth and reproductive characteristics depending on different climatic conditions, six sites with similar characteristics (edaphic, exposure, slope) burned in the summer of 1994 were selected along a climate gradient. Different precipitation values determined three different ombroclimates: dry-subhumid, dry and semi-arid. Ten years after the fires, data on growth and cone production were collected from these areas in order to study the pattern of growth and reproduction and the influence of site quality (climate) on them.

Results showed significantly higher values for growth and several cone characteristics; furthermore, they were positively related to site quality. Viability and seed germination percentages were higher in sites located in dry-subhumid areas. Serotiny was highest in dry locations (southern sites), and lower percentages were found in low tree density sites. The number of reproductive trees was higher northwards and the reproductive phase was reached in younger stands with lower tree density. In conclusion, results showed a geographical gradient based upon growth and reproductive characteristics, decreasing southwards in contrast to serotiny, which increases in southern sites. Density was found to be a significant factor influencing overall pine stand development.
\end{abstract}

Keywords: climatic gradient; serotiny; reproductive characteristics; site quality. 


\section{Introduction}

Aleppo pine (Pinus halepensis Mill.) is a conifer typically distributed in low elevation areas with poor soils [2] around the Mediterranean Basin. This species is an obligate seeder which has developed adaptive strategies to fire-prone areas [3]. After fire, regeneration is solely dependent on the canopy-stored seed bank. When the conditions are favourable, very dense pine stands may develop within the burned area [7]. Early cone-bearing is necessary for successful post-fire colonisation in areas of high fire recurrence, the earliest pine stand age was five years old [17]. These features depend on environmental conditions and site quality [18]. Serotiny is common among pine stands in fire-prone ecosystems [1] and can vary according to several factors, such as tree size and tree density [8]. Differences in cone production, pine tree growth and foliar nutrient content [9, $10,15]$ have been described for different fire events in various locations. In coetaneous regenerated stands (burned in the same year) in different locations along the eastern Iberian peninsula, growth, cone production, time to reach reproductive phase and serotiny have been related to site quality and tree density $[11,13]$ but aridity indices were not included.

The main goal of the present study was to relate aridity indices to growth or reproductive parameters. Therefore, our main hypothesis is that after a fire, naturally regenerated pine trees growing in the most xeric extreme will exhibit higher serotiny and a lower percentage of cone-bearing trees.

\section{Material and methods}

\subsection{Study area}

The data for this study were recorded in six different areas along an aridity gradient in the Eastern Iberian Peninsula where four large forest fires occurred in the summer of 1994(Figure 1). From north to south, the sites were: CAR and SUR (Barcelona), TAR (Tarragona), TUS and YES (Albacete) and CAL (Murcia). After the fires, the communities naturally regenerated and high Aleppo pine tree density stands were found [7, 19]. Also the slope and soil characteristics were similar in the study sites.

\subsection{Experimental design}

We established 24 circular plots $\left(r=10 \mathrm{~m}^{2}\right)$ in the study sites. The main tree species was young, naturally regenerated Aleppo pine trees. In each plot, 20-25 trees were randomly selected and monitored to record data during 2004. Tree height $(\mathrm{H})$ and trunk diameter (Dbase, $30 \mathrm{~cm}$ over the base) were measured for each pine tree monitored. Cones were counted in each pine tree, taking into account cone-bearing trees and the mature, serotinous and opened cones in that current year. Cone production is considered the number of all cones in the canopy and serotiny is the proportion of cones remaining closed after maturation [8]. Therefore, the serotiny level for the current year was calculated as the 
percentage of closed cones out of the total cone production. The percentage of reproductive trees (bearing at least one cone) was estimated for each plot to compare differences in the reproductive phase.

All of these factors were treated to obtain relationships with pine tree density and/or aridity. Pine tree density was estimated in each site by counting the total number of trees within a known area. The aridity was calculated with the De Martonne Aridity index (Im) defined as the ratio between the mean annual precipitation values $(\mathrm{P})$ and temperature $(\mathrm{T})$ plus $10^{\circ} \mathrm{C}[5]$.

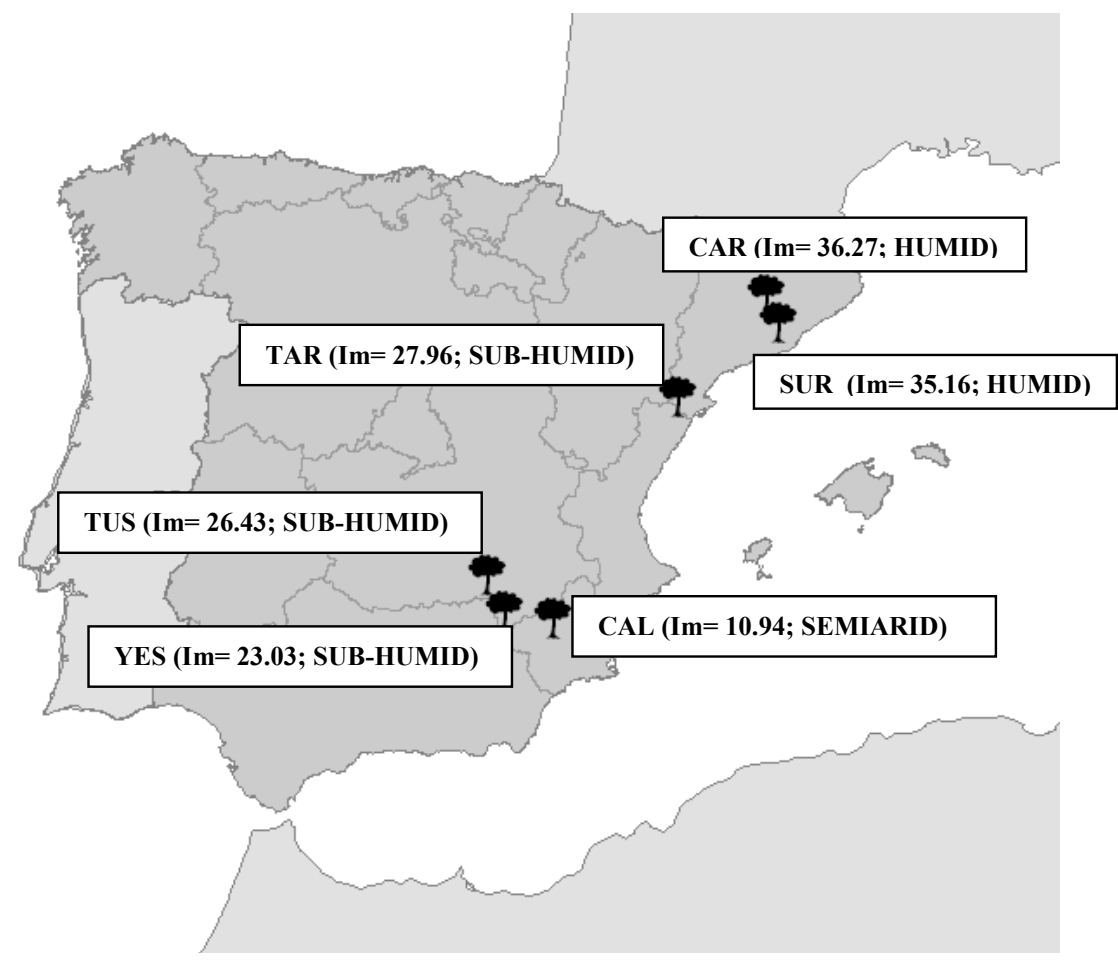

Figure 1: Study sites location along the eastern Iberian Peninsula: Cardona (CAR), Súria (SUR), Tarragona (TAR), Tus (TUS), Yeste (YES) and Calasparra (CAL). The sites include the De Martonne Aridity index (Im) and classification.

\subsection{Statistical analysis}

For all statistical analyses, assumptions of normality and homoscedasticity were tested and data were transformed using log or Varcsine transformation when required. Growth variables and reproductive parameters were analysed by stepwise multiple regressions. A General Linear Model (GLM) related the dependant variable to independent factors, including significance ( $p$ value) and 
variance $\left(\mathrm{R}^{2}\right)$. All statistical analyses were conducted using a critical $p$ value lower of 0.05 using the software Statgraphics Plus 5.1.

A PCA was carried out using aridity index, tree density, height, and diameter, number of reproductive trees, serotiny and cone production as variables to obtain their relationships. The first two components account for $63.74 \%$ of the variability in the original data.

Table 1: General Linear Models. Independent variables used in the models include their significance and the explained variance; nonsignificant factors were not included. Model 1 relates Cone Production $(\mathrm{CP})$ to number of reproductive trees (RT) and pine tree height $(\mathrm{H})$. Model 2 relates serotiny level $(\mathrm{S})$ to the De Martonne aridity index (Im), trunk diameter (Dbase), RT and TD interactions. Model 3 relates RT to Im, TD, Dbase and CP. Statistical analyses were conducted using a critical $P$ value of $\leq 0.05$.

\begin{tabular}{|c|c|c|c|c|c|c|c|c|}
\hline \multicolumn{3}{|c|}{$\begin{array}{l}\text { 1) } C P \\
\left(p=0.0017 ; R^{2}=50.67 \%\right)\end{array}$} & \multicolumn{3}{|c|}{$\begin{array}{l}\text { 2) } \mathrm{S} \\
\left.\text { ( } \mathrm{p}=0.0201 ; \mathrm{R}^{2}=43.03 \%\right)\end{array}$} & \multicolumn{3}{|c|}{$\begin{array}{l}\text { 3) RT } \\
\left(\mathrm{p}=0.0004 ; \mathrm{R}^{2}=97.13 \%\right)\end{array}$} \\
\hline & $\begin{array}{l}\mathrm{F} \\
\text { ratio }\end{array}$ & $p$ value & & $\begin{array}{l}\mathrm{F} \\
\text { ratio }\end{array}$ & $\begin{array}{l}p \\
\text { value }\end{array}$ & & F ratio & $\begin{array}{l}p \\
\text { value }\end{array}$ \\
\hline RT & 18.45 & 0.0004 & \multirow{2}{*}{$\begin{array}{l}\mathrm{Im}^{*} \mathrm{Dba} \\
\mathrm{se}\end{array}$} & \multirow[t]{2}{*}{11.60} & \multirow[t]{2}{*}{0.0034} & Im & 10.68 & 0.0024 \\
\hline $\mathrm{H}$ & 5.2 & 0.0350 & & & & $\mathrm{TD}$ & 5.56 & 0.0505 \\
\hline \multirow{3}{*}{\multicolumn{3}{|c|}{ Durbin-Watson = 1.58544}} & $\mathrm{Im} * \mathrm{RT}$ & 10.35 & 0.0051 & Dbase & 27.39 & 0.0012 \\
\hline & & & Dbase* & 5.17 & 0.0362 & $\mathrm{CP}$ & 52.48 & 0.0002 \\
\hline & & & TD & & & \multicolumn{3}{|c|}{ Durbin-Watson $=2.50844$} \\
\hline
\end{tabular}

\section{Results}

The H-Dbase relationship for Aleppo pine has been described in Moya et al. [11]. These factors were also related to the De Martonne Aridity index (Im). The linear regressions showed statistical significance $(p<0.05)$, obtaining the following equations with $\mathrm{R}^{2}=36.31 \%$ for $\mathrm{H}$ and $\mathrm{R}^{2}=15.69 \%$ for Dbase:

$\mathrm{H}=39.3597+4.26777 * \mathrm{Im}$

Dbase $=1.5855+0.0363609 * \mathrm{Im}$

Three GLM were developed to obtain relationships between Reproductive trees (RT), Serotiny (S) and cone production (CP) and between the factors studied. The analysis revealed different inter-relationships which are shown in Table 1.

The PCA analysis (Figure 2) confirmed that the previously obtained results summarized and focused our model. We decided to include two components, the first accounted for $36.80 \%$ and the second one $26.94 \%$, which when combined explained $63.74 \%$ of the variability obtained from the original data. This showed that $\mathrm{Im}$ was closely related to $\mathrm{H}$ and Dbase (as we proved) but was independent of pine tree density. Also, the high influence of pine tree density on S and $\mathrm{CP}$ was demonstrated in this analysis. 


\section{PCA}

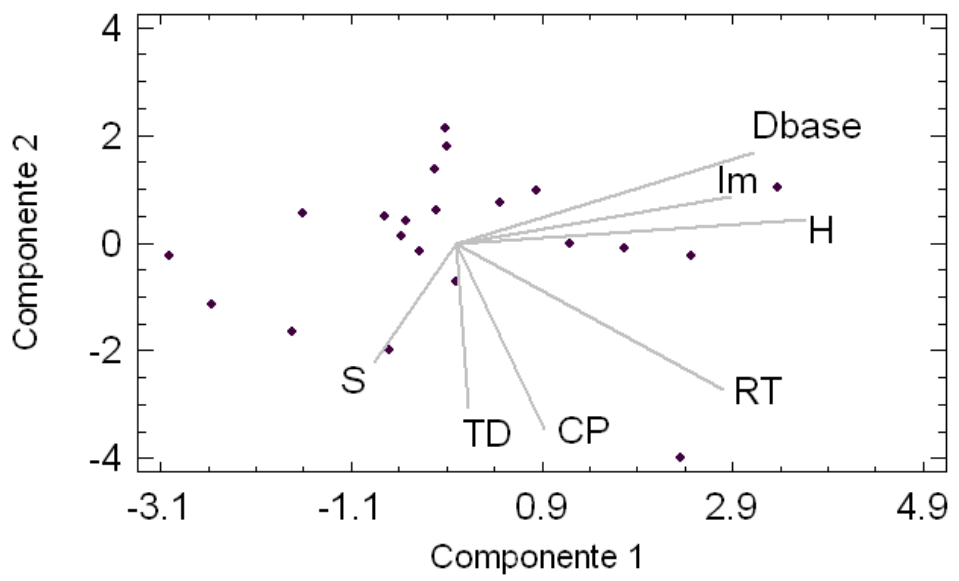

Figure 2: $\quad$ PCA analysis. Dbase: trunk diameter; Im: De Martonne aridity index; H: pine tree height; RT: number of reproductive trees; $\mathrm{CP}$ : cone production; TD: pine tree density; S: serotiny level. The first component accounts for $36.80 \%$ and the second component accounts for $26.94 \%$.

\section{Discussion}

The relationship between tree height and trunk diameter has been proven in several ages and locations for Aleppo pine $[4,16]$. It is difficult to compare pine tree development in stands with the same age in different locations; this has caused there to be a low number of studies relating allometric parameters to site quality $[6,13,19]$.

Early flowering and cone production is promoted by low pine tree density $[8$, $11,14]$, as per our results. Low pine tree density induces a lower intraspecific competition, so a higher amount of water, light and nutrients are available for the individuals. Also, many studies demonstrated that high fire recurrence, high pine tree density and low availability of water, light and nutrients promotes serotiny [17], but this factor is also related to trunk diameter and age $[4,8]$.

In this study, cone production was positively linked to pine height and the number of reproductive trees, in agreement with Verkaik et al. [19]. Thus, reducing tree density leads to greater increases in growth, a shortened period to reach the reproductive phase (higher number of reproductive trees) and higher cone production, although it could also result in a loss of seeds from the canopy seed bank $[7,12]$.

Aleppo pine trees distribute resources to prioritize growth; redistribution to serotinous cone production to prevent immaturity risk is secondary. When a minimal canopy seed bank is stored to ensure post-fire regeneration, seed 
dispersion (non-fire-based scenario) could be promoted. This was observed in the lower aridity sites (northern sites) but also in low pine tree density locations, where a high number of reproductive trees were found with high cone production. Therefore, high aridity was found to be correlated to slow tree development and high serotiny values corresponded with southern sites (serotiny level was almost 100\%). Ten years after a fire, Aleppo pine trees growing in northern locations (lower aridity) allocated more resources to growth, resulting in a higher number of reproductive trees and higher cone production, whereas pine trees growing in the southern dry and semiarid localities developed lower growth and with higher serotiny levels.

\section{References}

[1] Agee J.K., Fire and pine ecosystems, in: Richardson D.M. (Ed.), Ecology and biogeography of Pinus, Cambridge University Press, Cambridge. pp. 193-218. 1998

[2] Barbero M, Loisel R, Quezel P, Richardson D, Romane F. Pines of the Mediterranean Basin. In Richardson DM (ed) 'Ecology and Biogeography of Pinus'. pp. 153-166. Cambridge University Press: Cambridge. 1998

[3] Corona P, Leone V, Saracino A. Plot size and shape for the early assessment of post-fire regeneration in Aleppo pine Stands, New For. 16: 213-220. 1998.

[4] De las Heras J., Moya D., Lopez-Serrano F.R., Condes S. Reproduction of postfire Pinus halepensis Mill. stands six years after silvicultural treatments, Ann. For. Sci. 64: 59-66. 2007

[5] De Martonne E. Une nouvelle fonction climatologique: L'indice d'aridité. La Meteorologie, 449-458. 1926

[6] Gonzalez J.R., Pukkala T., Palia M., Optimising the management of Pinus sylvestris L. stand under risk of fire in Catalonia (north-east of Spain), Ann. For. Sci. 62: 493-501. 2005

[7] González-Ochoa AI, López-Serrano FR, de las Heras J. Does post-fire forest management increase tree growth and cone production in Pinus halepensis? For Ecol Manag 188: 235-247. 2004

[8] Goubitz, S., Nathan, R., Roitemberg, R., Shmida, A., Ne'eman, G. Canopy seed bank structure in relation to: fire, tree size and density. Plant Ecology 173, 191-201. 2004.

[9] López-Serrano FR, Las Heras J, Gonazalez-Ochoa AI, Garcia-Morote FA. Effects of silvicultural treatments and seasonal patterns on foliar nutrients in young post-fire Pinus halepensis forest stands. Forest Ecology and Management 210(1-3), 321-336. 2005.

[10] López-Serrano FR, de las Heras J, González-Ochoa AI, García-Morote FA, Landete TAM, Moya D, Del Cerro A (2006) Quercus ilex L. and Pinus halepensis Mill. Post-fire forest stands improve growth after thinning treatments as a consequence of a better availability of N. In Burke AR (ed) 'New Developments in Ecology Research' Nova Science Publisher, Inc: New York. pp. 99-139. 2006 
[11] Moya D, Espelta JM, Verkaik I, Lopez-Serrano FR, De las Heras J. Tree density and site quality influence on Pinus halepensis Mill. reproductive characteristics after large fires. Ann. For. Sci. 64: 649-656. 2007

[12] Moya D, De las Heras J, Lopez-Serrano FR, Leone V. Optimal intensity and age of management in young Aleppo pine stands for post-fire resilience. For Ecol Manag 255: 3270-3280. 2008

[13] Moya D, Espelta JM, Lopez-Serrano FR, Eugenio M, De las Heras J. Natural post-fire dynamics and serotiny in ten year-old Pinus halepensis Mill. stands along a geographic gradient. Int J of Wildland fire 17: 287292. 2008

[14] Moya D, Saracino A, Salvatore R, Lovreglio R, De las Heras J, Leone V. Anatomic basis and insulation of serotinous cones in Pinus halepensis Mill. Trees Struct and Func. DOI 10.1007/s00468-008-0211-1. 2008

[15] Pausas J.G., Gimeno T., Vallejo R., Fire severity and pine regeneration in the Eastern Iberian Peninsula, in: Viegas D. (Ed.), Forest field research and wildland fire safety, Millpress, Rotterdam. pp. 580-587. 2002

[16] Spanos IA, Daskalakou EN, Thanos CA. Postfire, natural regeneration of Pinus brutia forests in Thasos Island, Greece. Acta Oecologica 21 (1): 13-20. 2000

[17] Tapias R., Climent J., Pardos J.A., Gil L., Life histories of Mediterranean pines, Plant Ecol. 171: 53-68. 2004

[18] Thanos C.A., Daskalakou E.N., Reproduction in Pinus halepensis and P. brutia, in: Ne'eman G., Trabaud L. (Eds.), Ecology, biogeography and management of Pinus halepensis and P. brutia forest ecosystems in the Mediterranean basin, Bakhuys Publishers, Leiden. pp. 79-90. 2000

[19] Verkaik, I., Espelta, J.M. Post-fire regeneration thinning, cone production, serotiny and regeneration age in Pinus halepensis. Forest Ecology and Management 231, 155-163. 2006 